\title{
Improvement of bovine in vitro embryo production by fetal calf serum and cysteamine supplementation and investigation of freezability
}

\author{
Asiye İzem SANDAL ${ }^{1, a, \varpi}$, Hatice ŞENLIKC $\dot{I}^{1, b}$, Tuğba ELGÜN ${ }^{2, c}$, Ramazan ARICI ${ }^{1, d}$, \\ Sinem Özlem ENGINLER ${ }^{3, \mathrm{e}}$, Alper BARAN ${ }^{1, \mathrm{f}}$, Kemal AK ${ }^{1, \mathrm{~g}}$, Tülay İREZ ${ }^{2, \mathrm{~h}}$, Özen Banu ÖZDAŞŞ,i \\ ${ }^{1}$ İstanbul University-Cerrahpasa, Faculty of Veterinary Medicine, Department of Reproduction and Artificial Insemination, İstanbul; \\ ${ }^{2}$ Biruni University, Medical School, Department of Histology and Embryology, İstanbul; ${ }^{3}$ İstanbul University-Cerrahpasa, Faculty of \\ Veterinary Medicine, Department of Obstetrics and Gynecology, İstanbul, Turkey. \\ a ORCID: 0000-0002-4952-7861; ' ${ }^{\mathrm{a}}$ ORCID: 0000-0002-9568-2088; ' $\mathrm{ORCID:}$ 0000-0002-1311-6892; \\ ${ }^{\mathrm{d}}$ ORCID: 0000-0002-2239-2526; ' ${ }^{\mathrm{O}} \mathrm{ORCID}$ : 0000-0002-2352-876X; ${ }^{\mathrm{f}} \mathrm{ORCID:}$ 0000-0001-7053-3337; \\ gORCID: 0000-0002-4053-9655; hORCID: 0000-0001-8272-4931; ${ }^{\mathrm{i} O R C I D: 0000-0002-6867-5915}$
}

Corresponding author: izem@istanbul.edu.tr Received date: 30.01.2020 - Accepted date: 17.07.2020

\begin{abstract}
The aim of this study was to investigate the effects of cysteamine (Cys) and fetal calf serum (FCS) in synthetic oviduct fluid (SOF) and charles and rosenkrans (CR1aa) on the bovine in vitro embryo production and its ability of freeze. The oocytes were divided into two groups and allowed to mature in TCM-199, with and without cysteamine. They were divided into 4 subgroups according to whether they contain Cys and FCS in 2 different culture media (SOF and CR1aa). Accordingly, 8 groups were formed as SOF+FCS+Cys, SOF+Cys, SOF+FCS, SOF, CR1aa+FCS+Cys, CR1aa+Cys, CR1aa+FCS and CR1aa. Embryos were cultured for 79 days and were frozen using vitrification method. Development of embryos was observed during the first 24 hr post-thaw period. The highest rate of compact morula was $20 \%$ in SOF+FCS+Cys and $19.4 \%$ in CR1aa+FCS+Cys. The rate of blastocyst in SOF+FCS and CR1aa+FCS were found $17.9 \%$ and $15.4 \%$ respectively and the difference between groups was statistically significant $(\mathrm{P}<0.05)$. During the $12 \mathrm{hr}$ vitality assessment, the highest rate was determined in SOF+FCS (47\%). The results indicate that FCS has a positive effect in reaching compact morula and blastocyst regardless of the presence of the culture medium or antioxidant used. There was no statistically difference between the values of post-thaw embryos.
\end{abstract}

Keywords: Bovine, cysteamine, embryo, fetal calf serum, vitrification.

\section{Sığır in vitro embriyo üretiminin fetal buzağı serumu ve sisteamin katkısı ile iyileştirilmesi ve dondurulabilirliğinin araştırılması}

Özet: Bu çalışmanın amacı, sisteamin (Cys) ve fetal buzağı serumu (FCS)'nun sentetik oviduct sıvısı (SOF) ve charles ve rosenkrans (CR1aa) medyumlarında in vitro sığır embriyo üretimi ve donma kabiliyeti üzerindeki etkilerini araştırmaktır. Toplanan oositler iki gruba ayrıldı ve sisteaminli ve sisteaminsiz TCM-199 medyumunda maturasyonuna izin verildi. 2 farklı medyumda (SOF ve CR1aa) kültüre edilmek üzere Cys ve FCS içerip içermediklerine göre 4 alt gruba ayrıldı. Buna göre 8 alt grup; SOF+FCS+Cys, SOF+Cys, SOF+FCS, SOF, CR1aa+FCS+Cys, CR1aa+Cys, CR1aa+FCS ve CR1aa olarak oluşturuldu. Embriyolar 7-9 gün boyunca kültüre edildi ve vitrifikasyon yöntemi kullanılarak donduruldu. Çözdürme sonrası ilk 24 saat boyunca embriyonik gelişim gözlendi. Kompakt morula oranı en yüksek SOF+FCS+Cys'de \%20 ve CR1aa+FCS+Cys'de \%19,4 olarak bulundu. SOF+FCS ve CR1aa+FCS'deki blastosist oranı sırasıyla \%17,9 ve \%15,4 olarak saptandı ve gruplar arasındaki fark istatistiksel olarak anlamlıdı $(\mathrm{P}<0,05)$. En yüksek 12 saatlik canlılık değerlendirme oranı SOF+FCS'de (\%47) belirlendi. Elde edilen sonuçlar, kullanılan kültür ortamının veya antioksidanın varlığına bakılmaksızın FCS'nin kompakt morula ve blastosiste ulaşmada olumlu bir etkiye sahip olduğunu göstermektedir. Çözdürme sonrası embriyonik gelişimleri arasında istatistiksel olarak bir fark yoktu.

Anahtar sözcükler: Embriyo, fötal buzağı serumu, sı̆̆ır, sisteamin, vitrifikasyon.

\section{Introduction}

The success of reproductive technologies widely used in animals mainly depends on the cryopreservation of gamete cells and the embryo. Due to advances in technology and science, the vitrification method has gained popularity instead of slow freezing, which has been a standard method used in various animal species (27). 
During the period of in vitro mammalian embryo culture, atmospheric oxygen tension is routinely used, and this leads to the generation of reactive oxygen species (ROS) (14, 31). DNA damage, lipid peroxidation, oxidative modifications of proteins, and inhibition of oocyte and spermatozoon fusion are among the known detrimental effects of ROS (2). Moreover, ROS may develop under some conditions physiologically as an important factor in programmed cell death (apoptosis) (31, 34). ROS may originate directly from male and female gametes or embryos in different stages of embryonic development, but it may also originate as a result of environmental conditions (9). The most important endogenous source of ROS is oxidative phosphorylation. Inhibition of oxidative phosphorylation reduces ROS generation and has a positive effect on in vitro embryo development (29). Oxygen tension is the most important factor that increases ROS generation. The oxygen tension within the oviduct only equals to $1 / 4$ of the atmospheric oxygen tension. It was reported that the synthesis of glutathione (GSH), one of the non-protein sulfhydryl compounds, and freezing resistance in in vitro-produced bovine embryos increased under low oxygen tension (5$7 \%)(21,22)$. Antioxidants such as $\beta$-mercaptoethanol, cysteamine, cystine, cysteine, $\mathrm{N}$-acetyl-L-cysteine (NAC), resveratrol and superoxide dismutase (SOD) were used to protect in vitro-produced bovine embryos against oxidative stress $(4,15,32)$.

Essential amino acids, especially those that cannot be synthesized by the body, play a crucial role in embryo development $(12,33)$. However, although it has been reported that protein supplements used in bovine in vitro embryo production such as L-glutamine, fetal calf serum, fetal bovine serum, and bovine serum albumin were useful in the embryonic implantation stage $(16,19)$. In addition, some scientists have also stated that adding serums into in vitro culture medium resulted in some changes in the metabolism of embryos, which lead to accumulation of fatty acids (23) and increased the number of cytoplasmic lipid droplets (1) and eventually caused a decrease in cryotolerance of the cells (18). In particular, ammonia released by the metabolism of glutamine has some negative effects on the embryo $(11,24)$. Most importantly, ammonia is one of the main factors causing "large calf syndrome" (17). Therefore, serum-free media have been preferred in recent studies.

The ovarian tissues or cells are basically frozen by two methods. The first one is the traditional slow-freezing method, and the second one is the rapid freezing (vitrification) method. The vitrification method includes flash-freezing of the intracellular and extracellular water, forming a glass-like structure. The major advantage of this method is that it forms smaller ice crystals due to rapid and flash freezing, unlike the traditional slow freezing method (27).

There are many difficulties in genital cell freezing studies as known. It is up to new scientific studies to overcome all previously mentioned positive or negative situations. In our study bovine species preferred for the material, especially considering the contribution to the country livestock. Based on this information, we decided to investigate the effect of cysteamine and fetal calf serum on the production and freezability of in vitro bovine embryos.

\section{Material and Methods}

All chemicals are obtained from Sigma-Aldrich (St. Louis, Mo, USA).

Oocyte collection and selection: Bovine ovaries were obtained from a local slaughterhouse and transported to the laboratory within 2-3 $\mathrm{h}$ in dulbecco's phosphate buffered saline (D-PBS / FTTS) at 30-35 ${ }^{\circ} \mathrm{C}$. Oocytes collected by slicing method were assessed and only those with smooth cell walls, homogenous cytoplasm, undamaged zona pellucida and those with at least three or more layers of cumulus oophorus cells were selected.

Oocyte maturation: After 3 passages in HEPESbuffered TCM-199 (M5017) medium, with and without $100 \mu \mathrm{M}$ cysteamine (M9768), selected oocytes were washed in maturation medium (IVM-5\% FCS (F0804)) and transferred to $700 \mu \mathrm{l}$ IVM medium $(20-30$ oocytes/well). The cells were allowed to mature at $38.8^{\circ} \mathrm{C}$ in a $5 \% \mathrm{CO}_{2}$ incubator for $24 \mathrm{~h}$.

Fertilization of maturated oocytes: The oocytes with scattered cumulus oophorus cells around them were classified as mature. They were transferred to in vitro fertilization (IVF-TALP) medium and allowed to adapt to the new environment. The frozen straws of 2 Holstein bulls were thawed at $37^{\circ} \mathrm{C}$ for $30 \mathrm{sec}$. The sperm motility was examined and those of at least $45-60 \%$ motility were detected. Swim down method was preferred for sperm preparation. Washed spermatozoons were added on top of the oocytes $\left(400-600 \times 10^{3}\right.$ spermatozoon/well). The motility of oocytes and spermatozoon was then checked and allowed to fertilize for $18-22 \mathrm{~h}$ in $5 \% \mathrm{CO}_{2}$ at $38.8^{\circ} \mathrm{C}$.

Transfer of fertilized oocytes into the culture medium: The fertilized oocytes were transferred into $1 \mathrm{ml}$ of washing medium at $38.8^{\circ} \mathrm{C}$ (HEPES-buffered TCM199). After 1-minute mixing, fertilized zygotes were then cultured at $38.8{ }^{\circ} \mathrm{C}$ in $5 \% \mathrm{CO}_{2}, 5 \% \mathrm{~N}_{2}$ and $90 \%$ humidity for 7-9 days. 8 groups were formed such as SOF+FCS+Cys, SOF+Cys, SOF+FCS, SOF, CR1aa+FCS+Cys, CR1aa+Cys, CR1aa+FCS, and CR1aa. 5\% FCS was used in the serum groups.

Freezing mature embryos: At the end of the culture period, the healthy embryos reaching the blastocyst and expanded blastocyst stage in all groups in the presence of 
SOF and CR1 medium were selected and frozen using the vitrification method in straws. Equilibration solution (VS1) was $1.5 \mathrm{M}$ ethylene glycol (EG-E9129) and $1 \mathrm{M}$ dimethylsulfoxide (DMSO-D2650), and the vitrification solution (VS2) was 2.5 M EG, $2 \mathrm{M} \mathrm{DMSO}$ and $0.5 \mathrm{M}$ sucrose (S1888). For adaptation, selected embryos were kept in PBS droplets at room temperature. Firstly, the embryos were passaged in VS1 solution prepared as 3 separate $70 \mu \mathrm{l}$ drops for $3 \mathrm{~min}$. Then, they were placed in VS2 solution using the same volume and repetition count for $40 \mathrm{sec}$. 1 to 3 embryos were placed in pre-prepared embryo straws for freezing and sealed with polyvinyl alcohol (PVA). After the straws were sealed, they were immediately immersed into liquid nitrogen $\left(-196^{\circ} \mathrm{C}\right)$ and frozen.

Thawing of frozen embryos: Frozen embryo straws were pulled out of the liquid nitrogen after at least 1 week. After being kept at room temperature for $10 \mathrm{sec}$, they were directly thawed in the $37^{\circ} \mathrm{C}$ water-bath in $30 \mathrm{sec}$. The embryos were stored in a petri of $1 \mathrm{M}$ sucrose solution prepared with PBS containing 20\% FCS for 3 min. They were then taken into a $0.5 \mathrm{M}$ sucrose solution and allowed to stand for 1 minute there. Subsequently, they were transferred into HEPES-buffered TCM-199 for the removal of cryoprotectants.

The culture of thawed embryos: Thawed embryos were washed 3 times in HEPES-buffered TCM-199 medium and then cultured in SOF and CR1aa culture media of their groups. At the $12^{\text {th }}$ and $24^{\text {th }}$, the embryos were monitored to see whether they continued to develop after thawing.

Statistical analysis: Chi-square test in SPSS 13.0 package software was used for statistical analysis. P-value $<0.05$ was accepted statistically significant.

\section{Results}

The number of oocytes undergoing maturation during the study period was recorded as 1247. A total of 1019 cells proceed to in vitro culture immediately after in vitro fertilization. The mean cleavage rate of all groups was found to be $62.5 \%$. At the end of 7-9 days, the average rate of blastocyst stage was $20.2 \%$. The evaluation of the study results reveals that the highest cleavage rate belonged to the CR1aa+Cys group with $69.9 \%$, which was followed by the SOF+Cys group with $67.8 \%$ The group with the lowest rate was CR1aa+FCS with $58.2 \%$. Similarly, the SOF+FCS group showed a low cleavage rate of $57.8 \%$ (Table 1). The evaluation of other experimental groups revealed no statistical difference although there was a percentage difference between the rates of cleavage. Although there was no statistical difference between the groups in terms of division rates, in the blastocyst stage, the effects of FCS and cysteamine appeared differently in both cultures. While the highest cleavage rate of CR1aa medium with cysteamine (69.9\%) was achieved in the cleavage stage, the rate of reaching blastocysts decreased to $2.3 \%$. The lowest cleavage rate in the CR1aa medium with FCS was $58.2 \%$ and increased to

Table 1. Development of bovine embryos from cleavage to blastocyst stages after vitrification and IVC

\begin{tabular}{|c|c|c|c|c|c|c|c|c|c|}
\hline \multirow[b]{2}{*}{ Groups } & \multicolumn{5}{|c|}{$\begin{array}{c}\text { In Vitro Culture } \\
\text { n }(\%)\end{array}$} & \multicolumn{2}{|c|}{$\begin{array}{c}\text { Cryopreservation } \\
\mathbf{n}\end{array}$} & \multicolumn{2}{|c|}{$\begin{array}{l}\text { Viability } \\
\text { n (\%) }\end{array}$} \\
\hline & $\begin{array}{l}\text { Cleavaged } \\
\text { /cultured } \\
\text { cell }\end{array}$ & $\begin{array}{l}\text { Compact } \\
\text { morula/ } \\
\text { cleavaged }\end{array}$ & $\begin{array}{c}\text { Early } \\
\text { blastocyst/ } \\
\text { cleavaged }\end{array}$ & $\begin{array}{l}\text { Blastocyst/ } \\
\text { cleavaged }\end{array}$ & $\begin{array}{l}\text { Expanded } \\
\text { blastocyst/ } \\
\text { cleavaged }\end{array}$ & $\begin{array}{l}\text { Vitrified } \\
\text { embryos }\end{array}$ & $\begin{array}{l}\text { Thawed* } \\
\text { embryos }\end{array}$ & $\begin{array}{c}12 \mathrm{~h} / \\
\text { vitrified }\end{array}$ & $\begin{array}{c}24 \mathrm{~h} / \\
\text { vitrified }\end{array}$ \\
\hline SOF & $\begin{array}{l}78 / 120 \\
(65.0)\end{array}$ & $\begin{array}{l}4^{\mathrm{b} / 78} \\
(5.1)\end{array}$ & $\begin{array}{l}11 / 78 \\
(14.1)\end{array}$ & $\begin{array}{l}5^{\mathrm{b}} / 78 \\
(6.4)\end{array}$ & $\begin{array}{c}0 \\
(0)\end{array}$ & 16 & 15 & $\begin{array}{c}7 / 16 \\
(43.7)\end{array}$ & $\begin{array}{l}0 / 16 \\
(0)\end{array}$ \\
\hline SOF+FCS & $\begin{array}{l}67 / 116 \\
(57.8)\end{array}$ & $\begin{array}{l}8^{\mathrm{ab}} / 67 \\
(11.9)\end{array}$ & $\begin{array}{l}4 / 67 \\
(6.0)\end{array}$ & $\begin{array}{l}12^{\mathrm{a}} / 67 \\
(17.9)\end{array}$ & $\begin{array}{l}1 / 67 \\
(1.5)\end{array}$ & 17 & 15 & $\begin{array}{c}8 / 17 \\
(47.0)\end{array}$ & $\begin{array}{l}1 / 17 \\
(5.8)\end{array}$ \\
\hline SOF + Cys & $\begin{array}{l}78 / 115 \\
(67.8)\end{array}$ & $\begin{array}{l}10^{\mathrm{ab} / 78} \\
(12.8)\end{array}$ & $\begin{array}{l}3 / 78 \\
(3.8)\end{array}$ & $\begin{array}{l}10^{\mathrm{ab} / 78} \\
(12.8)\end{array}$ & $\begin{array}{l}1 / 78 \\
(1.3)\end{array}$ & 14 & 13 & $\begin{array}{c}5 / 14 \\
(35.7)\end{array}$ & $\begin{array}{l}1 / 14 \\
(7.1)\end{array}$ \\
\hline $\mathrm{SOF}+\mathrm{FCS}+\mathrm{Cys}$ & $\begin{array}{c}90 / 144 \\
(62.5)\end{array}$ & $\begin{array}{l}18 \mathrm{a} / 90 \\
(20.0)\end{array}$ & $\begin{array}{l}12 / 90 \\
(13.3)\end{array}$ & $\begin{array}{l}12^{\mathrm{ab} / 90} \\
(13.3)\end{array}$ & $\begin{array}{l}2 / 90 \\
(2.2)\end{array}$ & 26 & 23 & $\begin{array}{l}11 / 26 \\
(42.3)\end{array}$ & $\begin{array}{l}2 / 26 \\
(7.6)\end{array}$ \\
\hline CR1aa & $\begin{array}{l}67 / 115 \\
(58.3)\end{array}$ & $\begin{array}{l}4^{\mathrm{bc}} / 67 \\
(6.0)\end{array}$ & $\begin{array}{l}4 / 67 \\
(6.0)\end{array}$ & $\begin{array}{l}3^{\mathrm{b}} / 67 \\
(4.5)\end{array}$ & $\begin{array}{l}0 / 67 \\
(0)\end{array}$ & 7 & 7 & $\begin{array}{c}2 / 7 \\
(28.5)\end{array}$ & $\begin{array}{l}0 / 7 \\
(0)\end{array}$ \\
\hline CR1aa+FCS & $\begin{array}{l}78 / 134 \\
(58.2)\end{array}$ & $\begin{array}{l}11^{\mathrm{ab} / 78} \\
(14.1)\end{array}$ & $\begin{array}{c}8 / 78 \\
(10.3)\end{array}$ & $\begin{array}{l}12^{\mathrm{a} / 78} \\
(15.4)\end{array}$ & $\begin{array}{l}0 / 78 \\
(0)\end{array}$ & 20 & 18 & $\begin{array}{l}8 / 20 \\
(40.0)\end{array}$ & $\begin{array}{l}1 / 20 \\
(5.0)\end{array}$ \\
\hline CR1aa+Cys & $\begin{array}{l}86 / 123 \\
(69.9)\end{array}$ & $\begin{array}{l}3 c / 86 \\
(3.5)\end{array}$ & $\begin{array}{l}10 / 86 \\
(11.6)\end{array}$ & $\begin{array}{l}2^{\mathrm{b}} / 86 \\
(2.3)\end{array}$ & $\begin{array}{l}0 / 86 \\
(0)\end{array}$ & 12 & 11 & $\begin{array}{l}3 / 12 \\
(25.0)\end{array}$ & $\begin{array}{l}0 / 12 \\
(0)\end{array}$ \\
\hline CR1aa+FCS+Cys & $\begin{array}{l}93 / 152 \\
(61.2)\end{array}$ & $\begin{array}{l}18 \mathrm{a} / 93 \\
(19.4)\end{array}$ & $\begin{array}{l}7 / 93 \\
(7.5)\end{array}$ & $\begin{array}{l}8^{\mathrm{b}} / 93 \\
(8.6)\end{array}$ & $\begin{array}{l}3 / 93 \\
(3.2)\end{array}$ & 18 & 14 & $\begin{array}{c}6 / 18 \\
(33.3)\end{array}$ & $\begin{array}{l}1 / 18 \\
(5.5)\end{array}$ \\
\hline
\end{tabular}

\footnotetext{
*Number of cultured embryos after thawing
} 
$15.4 \%$ when reaching blastocyst. In the same perspective, the low rate of cleavage in the SOF medium with FCS (57.8\%) and increased to $17.9 \%$ when reaching blastocyst stage. This suggests that the use of cysteamine and fetal calf serum in different culture media have no effects on the cleavage or blastocyst stages. A total of 130 embryos were obtained, which were frozen using vitrification and found to be at different developmental stages at the end of in vitro culture after the thawing process. The viability assessment of embryos was performed in $12 \mathrm{~h}$ and $24 \mathrm{~h}$ after the thawing. From the $12 \mathrm{~h}$ onwards, degenerations were observed. By the end of the $24 \mathrm{~h}$, embryonic development stopped in all groups. The rates of reaching all of embryonic stages and viability rates between groups are given in Table 1.

\section{Discussion and Conclusion}

In a study, Sovernigo et al. (28) investigated the effects of different antioxidant supplements on the development of embryos and found that quercetin, vitamin $\mathrm{C}$, resveratrol, and carnitine did not affect the rate of cleavage and reaching the blastocyst stage. These results are in parallel with the results of the research conducted by Sandal and Ozdas (26), Enginler et al. (7), Anchordoquy et al. (3) and Kharche et al. (13) also reported that the supplementation of $100 \mu \mathrm{M}$ cysteamine did not result in a statistically significant in cleavage rates. Although many studies have reported that FCS has a positive effect on embryo development, it is known that the incidence of large calf syndrome is high among offsprings born as a result of the transfer of embryos, which were developed in a high-protein-containing medium (25). Therefore, serum-free media have been preferred in recent studies $(8,10,30)$. Some researchers argue that the use of FCS in the in vitro culture stage leads to high lipid accumulation in blastocysts, and deteriorates embryo quality (5). According to the results obtained in the study, the low rates of cleavage in the serum and cysteamine-free groups (SOF+FCS and CR1aa+FCS), regardless of the culture medium used, seems to support this argument $(11,17)$. In a study, Murillo et al. (20) developed bovine embryos both $(5 \%)$ in and without FCS and did not detect a statistical difference in their development stages up to morula, however, they found a statistical difference in the early blastocyst stage $(\mathrm{P}<0.005)$. In this study, a statistical difference was found in the compact morula and blastocyst stages in favor of the groups that used FCS compared to the other groups. Gomez et al. (8) in their study, they preferred FCS $(5 \%)$ and BSA $\left(20 \mathrm{~g} \mathrm{~L}^{1}\right)$ in SOF medium of bovine embryo culture. The researchers achieved the best blastocyst development rate in the FCS group $(21.2 \%)$ and found a statistical difference compared to other groups $(\mathrm{P}<0.05)$. It is seen that this result and our result $(17.9 \%)$ are parallel to each other. Duque et al. (6) reported the rate of bovine embryos that they produced in vitro in the SOF medium containing $5 \%$ FCS as $21.1 \%$ and found a statistical difference between the blastocyst rate $(6.6 \%)$ found in the culture medium they did not add serum. In this study, the rate of reaching blastocyst in the SOF group (6.4\%) and the rate of blastocyst in the SOF+FCS group (17.9\%) is similar to Duque et al. (6)'s results. When the SOF+FCS, $\mathrm{SOF}+\mathrm{Cys}$ and $\mathrm{SOF}+\mathrm{FCS}+\mathrm{Cys}$ groups of the study were examined, there was no statistical difference even in the percentage of achieving the blastocyst and compact morula stages. This result suggests that the combination of FCS and Cys may have an antagonistic effect on embryo development. Considering the CR1aa+FCS (15.4\%), CR1aa+Cys (2.3\%) and CR1aa+FCS+Cys (8.6\%) groups of the study, it shows similar results in terms of the rate of reaching blastocyst compared to the same SOF groups. This situation gives us the positive effects of FCS and Cys on embryo development when used separately; it suggests that when used in combine, the effect turns into either a negative or antagonist type. The presence of antagonist effect is evident from the statistical difference between CR1aa+FCS and CR1aa+ FCS+Cys groups ( $\mathrm{P}<0.05)$. These results show that FCS has a positive effect on the development of embryos even in the absence of antioxidants in the blastocyst stage. This appears to be consistent with the study carried out by Murillo et al. (20), which argued that the use of low concentration of FCS has a positive effect on the development of embryos. To make a comparison in terms of culture media, which are frequently preferred in bovine in vitro embryo culture; CR1aa appears to need more serum or protein addition than SOF (30). The fact that the blastocyst rate obtained in a study of Wan et al. (30) was higher in the CR1aa+BSA+FCS group compared to other groups and statistically different from other groups $(25.5 \%)$ is an indicator of this. Likewise, in this study the blastocyst ratios of embryos developed in CR1aa medium are lower than the SOF medium supports that SOF is more preferable in bovine in vitro embryo culture.

As a result of the study, it can be concluded that SOF+FCS can support bovine IVC embryos developing to blastocyst with the same efficiency as $\mathrm{SOF}+\mathrm{FCS}+\mathrm{Cys}$ or SOF + Cys, but combination of $5 \%$ FCS and $100 \mu \mathrm{M}$ cysteamine in CR1aa medium show an antagonist effect and affect the development of bovine embryos negatively.

\section{Financial Support}

This study was supported by Istanbul University Research Fund with the project number 55727. 


\section{Ethical Statement}

This study does not present any ethical concerns.

\section{Conflict of Interest}

The authors declared that there is no conflict of interest.

\section{References}

1. Abe H, Yamashita S, Itoh T, et al (1999): Ultrastructure of bovine embryos developed from in vitro matured and fertilized oocytes: Comparative morphological evaluation of embryos cultured either in serum free medium or serum supplemented medium. Mol Reprod Dev, 53, 325-335.

2. Aitken RJ, Harkiss D, Buckingham D (1993): Relationship between iron-catalysed lipid peroxidation potential and human sperm function. J Reprod Fertil, 98, 257-265.

3. Anchordoquy JM, Anchordoquy JP, Testa JA, et al (2015): Influence of vascular endothelial growth factor and Cysteamine on in vitro bovine oocyte maturation and subsequent embryo development. Cell Biol Int, 39, 10901098.

4. Balasubramanian S, Rho GJ (2007): Effect of cysteamine supplementation of in vitro matured bovine oocytes on chilling sensitivity and development of embryos. Anim Reprod Sci, 98, 282-292.

5. Do VH, Walton S, Taylor-Robinson AW (2016): Improvements to in vitro culture media for use in bovine IVF. J Vet Sci Anim Husb, 4, 205.

6. Duque P, Gomez E, Diaz E, et al (2003): Use of two serum during bovine embryo culture in vitro. Theriogenology, $\mathbf{5 9}$, 889-899.

7. Enginler SO, Ozdaş OB, Sandal AI, et al (2016): The effect of cysteamine and oviductal cells in different culture media on the development of sheep embryos. Kafkas Univ Vet Fak, 22, 139-145.

8. Gomez E, Rodriguez A, Munoz M, et al (2008): Serum free embryo culture medium improves in vitro survival of bovine blastocysts to vitrification. Theriogenology, 69, 1013-1021.

9. Guerin P, El Mouatassim S, Menezo Y (2001): Oxidative stress and protection against reactive oxygen species in the pre-implantation embryo and its surroundings. Hum Reprod Update, 7, 175-189.

10. Hajarian H, Aghaz F, Karami Shabankareh H (2017): Replacement of serum with sericin in in vitro maturation and culture media: Effects on embryonic developmental competence of Sanjabi sheep embryo during breeding season. Theriogenology, 92, 144-148.

11. Hammon DS, Wang S, Holyoak GR (2000): Effects of ammonia during different stages of culture on development of in vitro produced bovine embryos. Anim Reprod Sci, 59, 23-30.

12. Hong J, Lee E (2007): Intrafollicular amino acid concentration and the effect of amino acids in a defined maturation medium on porcine oocyte maturation, fertilization, and preimplantation development. Theriogenology, 68, 728-735.
13. Kharche SD, Agrawal S, Pathak J, et al (2016): Influence of cysteamine supplementation during in vitro culture of early stage caprine embryos on blastocyst production. Indian J Anim Sci, 86, 304-306.

14. Kitagawa Y, Suzuki K, Yoneda A, et al (2004): Effects of oxygen concentration and antioxidants on the in vitro developmental ability, production of reactive oxygen species (ROS), and DNA fragmentation in porcine embryos. Theriogenology, 62, 1186-1197.

15. Kobayashi M, Lee ES, Fukui Y (2006): Cysteamine or $\beta$ mercaptoethanol added to defined maturation medium improves blastocyst formation of porcine oocytes after intracytoplasmic sperm injection. Theriogenology, $\mathbf{6 5}$, 1191-1199.

16. Kuran M, Robinson JJ, Staines ME, et al (2001): Development and de novo protein synthetic activity of bovine embryos produced in vitro in different culture systems. Theriogenology, 55, 593-606.

17. Lane M, Gardner DK (1994): Increase in postimplantation development of cultured mouse embryos by amino acids and induction of fetal retardation and exencephaly by ammonium ions. J Reprod Fertil, 102, 305312.

18. Moore K, Rodriguez-Sallaberry CJ, Kramer JM, et al (2007): In vitro production of bovine embryos in medium supplemented with a serum replacer: Effects on blastocyst development, cryotolerance and survival to term. Theriogenology, 68, 1316-1325.

19. Murillo-Ríos A, Maillo V, Muñoz M, et al (2017): Shortand long-term outcomes of the absence of protein during bovine blastocyst formation in vitro. Reprod Fert Develop, 29, 1064-1073.

20. Murillo A, Muñoz M, Martín-González D, et al (2017): Low serum concentration in bovine embryo culture enhances early blastocyst rates on Day-6 with quality traits in the expanded blastocyst stage similar to BSA-cultured embryos. Reprod Biology, 17, 162-171.

21. Oyamada T, Fukui Y (2004): Oxygen tension and medium supplements for in vitro maturation of bovine oocytes cultured individually in a chemically defined medium. J Reprod Develop, 50, 107-117.

22. Raty M, Ketoja E, Pitkanen T, et al (2011): In vitro maturation supplements affect developmental competence of bovine cumulus-oocyte complexes and embryo quality after vitrification. Cryobiology, 63, 245-255.

23. Reis A, Rooke JA, McCallum GJ, et al (2003): Consequences of exposure to serum, with or without vitamin E supplementation, in terms of the fatty acid content and viability of bovine blastocysts produced in vitro. Reprod Fert Develop, 15, 275-284.

24. Rooke JA, Ewen M, Mackie K, et al (2004): Effect of ammonium chloride on the growth and metabolism of bovine ovarian granulosa cells and the development of ovine oocytes matured in the presence of bovine granulosa cells previously exposed to ammonium chloride. Anim Reprod Sci, 84, 53-71.

25. Sağırkaya H, Mısırlıoğlu M, Kayaç A, et al (2007): Developmental potential of bovine oocytes cultured in different maturation and culture conditions. Anim Reprod Sci, 101, 225-240. 
26. Sandal AI, Ozdaş OB (2015): Vitrification of in vitroproduced bovine embryos matured in modified TCM-199 medium. Turk J Vet Anim Sci, 39, 688-692.

27. Saragusty J, Arav A (2011): Current progress in oocyte and embryo cryopreservation by slow freezing and vitrification. Reproduction, 141, 1-19.

28. Sovernigo TC, Adona PR, Monzani PS, et al (2017): Effects of supplementation of medium with different antioxidants during in vitro maturation of bovine oocytes on subsequent embryo production. Reprod Domest Anim, 52, 561-569.

29. Thompson JG, McNaughton C, Gasparrini B, et al (2000): Effects of inhibitors and uncouplers of oxidative phosphorylation during compaction and blastulation of bovine embryos cultured in vitro. J Reprod Fertil, 118, 4755.

30. Wan P, Hao Z, Zhou P, et al (2009): Effects of SOF and CRI media on developmental competence and cell apoptosis of ovine in vitro fertilization embryos. Anim Reprod Sci, 114, 279-288.

31. Valk JVD, Brunner D, Smet KD, et al (2010): Optimization of chemically defined cell culture media Replacing fetal bovine serum in mammalian in vitro methods. Toxicol in Vitro, 24, 1053-1063.

32. Van Soom A, Yuan YQ, Peelman LJ, et al (2002): Prevalence of apoptosis and inner cell allocation in bovine embryos cultured under different oxygen tensions with or without cysteine addition. Theriogenology, 57, 1453-1465.

33. Zabihi A, Shabankareh HK, Hajarian H, et al (2019): Resveratrol addition to in vitro maturation and in vitroculture media enhances developmental competence of sheep embryos. Domest Anim Endocrin, 68, 25-31.

34. Zolini AM, Carrascal-Trianaa E, Ruiz de Kinga A, et al (2019): Effect of addition of L-carnitine to media for oocyte maturation and embryo culture on development and cryotolerance of bovine embryos produced in vitro. Theriogenology, 133, 135-143. 